\title{
THE MATERIAL LAW PROTECTION OF WILD ANIMALS
}

\author{
by JP Liebenberg*
}

\section{Introduction}

The aim of this article is to consider the protection of wild animals and other living natural resources in South Africa from a material law perspective. To ensure completeness both the procedural law and problems with enforcement will be briefly considered. Possible improvements and solutions to difficulties will also be submitted.

This article will focus mostly on the pre-1994 conservation ordinances ${ }^{1}$ which still apply in the nine new provinces. ${ }^{2}$ Wild animals are protected in these provincial laws on a species based approach where animals are listed in categories and each category is provided with a different degree of protection. ${ }^{3}$ These ordinances are the main source of law which deal with the conservation, protection and exploitation of wild animals, indigenous plants and freshwater fish in South Africa and is usually referred to as 'wildlife law.'4

\section{History, development and scope of conservation law}

The origins of conservation law can be traced back to the seventeenth century where, upon the arrival of colonial settlers in the Cape, five placaats were promulgated to protect gardens, lands and trees from destruction. ${ }^{5}$ After the creation of the Union of South Africa in 1910, nature conservation was left as a matter of provincial competence and their respective nature conservation departments. ${ }^{6}$ The current South African Constitution designates nature conservation to be a matter of concurrent competence of the national and provincial spheres of government. ${ }^{7}$

\footnotetext{
J Liebenberg, fourth year LLB student, University of Pretoria.

Ordinance 19 of 1974 of the Cape; Ordinance 8 of 1969 of the Free State; Ordinance 12 of 1983 of Transvaal; Ordinance 15 of 1974 of Natal and the previous homelands had their own conservation laws which still apply.

Glazewski Environmental Law in South Africa (2005) 365.

As above.

As above.

As above; Rabie \& Fuggle Environmental management (1992) 13.

Glazewski (n 3 above) 365.

As above.
} 
Historically, these ordinances have been focussed on the establishment of protected areas, the conservation of wild animals, indigenous plants and freshwater fish; which was also thought of as the full scope of nature conservation. ${ }^{8}$ More recently, this way of thought has been put aside to make way for a much broader definition which encompasses more than just conservation and includes management and income generation in order to conserve biodiversity and sustain life support systems and ecosystems of interdependent species. 9 The main focus has been on the idea to make conservation profitable, this is as result of the government's decreasing ability and willingness to subsidise the managing of protected areas. ${ }^{10}$

Societal pressure has also recently been increasing for the ethical treatment of animals, which raises a Constitutional question of the rights of animals, which is discussed below. ${ }^{11}$ Other aspects, like laws relating to hunting, ecotourism and recreation should also be included and seen in this context. ${ }^{12}$

After the adoption of the Interim and Final Constitution the four provinces became nine and incorporated the four homelands, which had their own individual laws relating to conservation. ${ }^{13}$

Nature conservation is now a matter of national as well as provincial concurrent competence, many of the previous nature conservation authorities are now also burdened with administering environmental management laws without having the capacity or the knowledge and expertise to do so. ${ }^{14}$ This added responsibility has led to a type of 'legal pluralism' that Du Plessis describes as 'legal chaos'. ${ }^{15}$ This confusion has been alleviated to some extent with the promulgation of the Environmental Conservation Extension Act 100 of 1996 and the Environmental Laws Rationalisation Act 51 of $1997 .{ }^{16}$

\section{International law}

\subsection{International wildlife agencies}

The main international and inter-governmental agencies dealing with international aspects of wildlife are the United Nations Environmental Program (UNEP) and the United Nations Commission on Sustainable

As above.

As above.

As above.

As discussed in part 4 of this paper.

Glazewski (n 3 above) 366.

As above.

As above.

As above; Du Plessis 'Integration of exiting environmental legislation in the Provinces' (1995) 2 South African Journal of Environmental Law and Policy 23.

16 Glazewski (n 3 above) 366. 
Development (CSD). ${ }^{17}$ They are responsible for the formulation of the Principles for Global Consensus on the Management, Conservation and Sustainable Development of all Types of Forests (UNCED Forest Principles) and Agenda 21. ${ }^{18}$ UNEP is responsible for the adoption of many of the wildlife conventions to which South Africa is a party. ${ }^{19}$

The World Conservation Union (WCU) is the most important international non-governmental organisation, which includes both governmental and non-governmental members, which has been playing a very important role in developing treaties to conserve natural resources and wildlife. ${ }^{20}$ For example, it played an important role in preparing the preliminary texts for a number of conventions which have been developed at later negotiations like the International Convention on Biodiversity. ${ }^{21}$ Other active NGO's in the field of nature conservation include Greenpeace, Friends of the Earth and the World Wildlife Fund (WWF). ${ }^{22}$

\subsection{International wildlife conventions}

Important wildlife conventions that South Africa has adopted include: the 1973 Convention on International Trade in Endangered Species of Wild Fauna and Flora (CITES); the Convention on the Conservation of Migratory Species of Wild Animals (the Bonn Convention or the CMS) and the Convention on Biological Diversity. ${ }^{23}$

\section{The Constitution and wildlife protection}

\subsection{Wildlife rights and the Bill of Rights}

South Africa has one of the most progressive and liberal Constitutions and Bill of Rights in the world, yet it does not go so far as to confer rights to animals. ${ }^{24}$ This was done despite animal rights groups campaigning vigorously for the inclusion of animal rights during the negotiation process of the South African Constitution. ${ }^{25}$ It is submitted that a reasonable compromise which would probably have satisfied animal rights groups would have been, instead of giving animals rights, giving people a duty to treat animals humanely. ${ }^{26}$ 
The focus on animal rights conforms to international trends as more attention is being paid to the topic of animal rights and the ethical treatment of animals. ${ }^{27}$

The proponents of animal rights argue that animals suffer if mistreated just like human beings and that rights should not be arbitrarily withheld from the one species and not the other. ${ }^{28}$ Although some of their arguments are valid and thought provoking, the ultimate aim of the animal rights movement is to eliminate human use and exploitation of animals. ${ }^{29}$ It is submitted that this is disproportionate and does not accord with the interests of society.

The ethical concerns about the humane treatment, prevention of cruelty and unnecessary killing of animals have been raised locally in South Africa along with the international community. ${ }^{30}$ This is evident from the promulgation of South African legislation like the Animals Protection Act 71 of 1962, the Performing Animals Act 24 of 1935 and the Societies for the Prevention of Cruelty to Animals Act 169 of 1993. ${ }^{31}$ These acts protect domestic animals mostly but do include wild animals in their ambit. 32

The argument to extend some rights to animals is a valid one and not completely unrealistic if one considers that slaves and women used to be thought of as having no rights. ${ }^{33}$ All of the above aside, it is probably not the right time in South Africa's political context to consider animal and wildlife rights, as inequalities on the human front are still to be dealt with properly. 34

\subsection{The Constitution and administration of nature conservation}

As indicated above, ${ }^{35}$ nature conservation has historically been under the complete control of the provinces independently. ${ }^{36}$ The Constitution has now changed that by stating: 'Nature conservation excluding national parks, national botanical gardens and marine resources' is a matter of concurrent national and provincial competence. ${ }^{37}$ The same is true for the 'environment' which is also

As above.

As above.

As above.

As above.

As above.

As above.

As above.

As above.

As discussed in part 1 of this paper.

Glazewski (n 3 above) 371.

Glazewski (n 3 above) 371; Constitution of the Republic of South Africa, 1996, Schedule 4. 
subject to concurrent competence of national and provincial control. 38

\section{Nature conservation laws in the former provinces and homelands}

\subsection{Introduction}

It is necessary to deal with the four nature conservation ordinances from the previous four provinces because they are still in place and still apply in some of the new nine provinces as they exist today. ${ }^{39}$ They are applied as follows:

- Nature and Environmental Conservation Ordinance (Cape); ${ }^{40}$ applies to the new provinces of Western Cape, Eastern Cape and Northern Cape and to some areas of the North West. ${ }^{41}$

- Nature Conservation Ordinance (Transvaal); 42 applies to Gauteng and the Northern Province. ${ }^{43}$ Mpumalanga province, which was part of the Transvaal, has adopted and passed new legislation and will be seen in paragraph 3.7.

- Nature Conservation Ordinance (Orange Free State); ${ }^{44}$ still applies in the Free State Province.

- Nature Conservation Ordinance (Natal); ${ }^{45}$ applied in KwaZulu-Natal but has been substantially supplemented by the KwaZulu-Natal Nature Conservation Management Act, ${ }^{46}$ which is elaborated in paragraph 4(7), as well as by the KwaZulu-Natal Nature Conservation Management Amendment Acts. ${ }^{47}$

\subsection{General approach in the Provincial ordinances}

\subsubsection{Introduction}

The general approach, which all four provinces have used, is to distinguish between conservation inside and outside reserves. ${ }^{48}$ Each

Glazewski (n 3 above) 371; Constitution of the Republic of South Africa, 1996 , Schedule 4.

Glazewski (n 3 above) 371.

Ordinance 19 of 1974.

Amended by the Western Cape Nature Conservation Laws Amendment Act 3 of 2000; Glazewski (n 3 above) 374.

Ordinance 2 of 1983.

The Cape Ordinance and former Bophuthatswana legislation also applies in the North West Province; Glazewski (n 3 above) 374.

Ordinance 8 of 1969.

Ordinance 15 of 1974

Act 9 of 1997.

Acts 5 of 1999 and 7 of 1999; Glazewski (n 3 above) 374.

Glazewski (n 3 above) 375. 
of the ordinances contains enabling provisions which allow the provincial authorities to establish provincial reserves. ${ }^{49}$ Outside reserves, the focus is more directed to the protection of an individual species of animal or plant, rather than the protection of entire ecosystems. ${ }^{50}$ The four ordinances do not mention threatened or endangered species specifically but rather refer to general categories like 'ordinary game', 'protected game' and 'specially protected game' and these then contain lists of specific species. ${ }^{51}$ The respective schedules of the old ordinances and the new provincial laws provide for the following categories:

- The Cape Ordinance ${ }^{52}$ lists the following categories: protected wild animals; endangered flora; protected flora; noxious aquatic growths. ${ }^{53}$

- The Orange Free State Ordinance ${ }^{54}$ lists the following six categories: protected game; ordinary game; specified wild animals; exotic animals; aquatic plants and protected plants. ${ }^{55}$ Also in a later schedule 'Hunting at night' is mentioned and lists the species to which the provisions apply. ${ }^{56}$

- The Transvaal Ordinance ${ }^{57}$ lists the following twelve categories: protected game(including a sub schedule on specially protected game); ordinary game; protected wild animals; wild animals to which s43 applies (this deals with the possession of certain listed wild animals); exotic animals; invertebrates; problem animals; trout waters; prohibited aquatic growths; protected plants and specially protected plants. ${ }^{58}$

- Mpumalanga Nature Conservation $\mathrm{Act}^{59}$ list the following fourteen categories in its schedules: specially protected game; protected game(this schedule includes amphibians, reptiles, mammals and birds); ordinary game; protected wild animals; wild animals to which the provisions of $\mathrm{s} 33$ do not apply (this section deals with possession); exotic animals to which s34 applies (this section deals with certain prohibitions); invertebrates; problem animals; fly fishing waters; prohibited aquatic growths; protected plants; specially protected plants; invader weeds and plants; unique communities. ${ }^{60}$ This Act repealed the KaNgwane Nature Conservation Act 3 of $1981 .^{61}$

As above.

As above.

As above.

Ordinance 19 of 1974.

Schedule 1 to 5; Glazewski (n 3 above) 375.

Ordinance 8 of 1969.

Schedule 1 to 6; Glazewski (n 3 above) 375.

Schedule 8; Glazewski (n 3 above) 375.

Ordinance 12 of 1983.

Schedules 2 to 12; Glazewski (n 3 above) 375.

Act 10 of 1998.

Schedules in Act 10 of 1998; Glazewski (n 3 above) 375.

Glazewski (n 3 above) 375. 
- The KwaZulu-Natal Conservation Amendment Act ${ }^{62}$ lists the following four categories to which different degrees of protection apply: ${ }^{63}$ specially protected indigenous animals; protected indigenous animals; specially protected indigenous plants and protected indigenous plants. 64

One can see a similarity in all these lists of the different protected categories, although they are not the same, the word 'game' is mentioned in all of them except for the Cape Ordinance, probably because hunting is not that predominant, at least in the Western Cape, although quite a big generator of income for the Eastern Cape. 65

\subsubsection{Summary}

The schedules above protect species in various different ways in the respective provinces; some have absolute protection; whilst others have permit requirements like bag limits, hunting seasons, prohibitions on certain hunting methods, etc. ${ }^{66}$ This system of provincial regulation holds many advantages because a certain species might be endangered in one province but not in others or, one species may be a problem in one province but not in others. ${ }^{67}$ It is therefore, easily adaptable to local ecological circumstances. ${ }^{68}$ One of the problems of this system is that it requires constant vigilance and maintenance by the entire community to make sure that it remains up to date and it also demands the monitoring of different species in the provinces and, thus requires a rather complicated administrative and technical infrastructure which is sometimes beyond the capabilities of the under-resourced provincial governments. ${ }^{69}$

\subsection{Administration of the conservation laws}

Many of the provinces have moved towards the trend of converting their respective nature conservation departments into statutory authorities in the form of Boards, following the lead of KwaZulu-Natal and their Nature Conservation Service (KZN NCS) which are, arguably, the leaders in nature conservation in South Africa. ${ }^{70}$ The national sphere has also done this with the South African National Parks (SANP, formerly the National Parks Board).

Act 5 of 1999.

Glazewski (n 3 above) 375.

Schedule 7; Glazewski (n 3 above) 375.

Glazewski (n 3 above) 376.

As above.

As above.

As above.

As above.

As above. 
The main issue with this is that the boards in the different provinces have very different types of jurisdictions. ${ }^{71}$ Some have placed only nature conservation, and not environmental management, as their sole competence, others are considering placing only protected areas under their jurisdiction and leaving general nature conservation outside reserves in the hands of the provincial authorities. ${ }^{72}$

\subsection{The conservation of wild animals}

Most of the Provincial Ordinances referred to above refer to both 'wild animals' and 'game.' The former, generally, is widely defined; the Cape Provincial Ordinance, for instance, defines wild animals as follows: 73

Any live vertebrate animals (including bird or reptile or the egg of such animal, bird or reptile but excluding any fish or any ostrich used for farming purposes and the egg thereof) belonging to a non-domestic species and includes any such animal which is kept or has been born in captivity.

None of the Provincial Ordinances refer to ownership of wild animals and it is, therefore, left to the common law. ${ }^{74}$ The South West African Ordinance, which still applies in Namibia, has a similar provision to the Game Theft Act with regard to ownership of wild animals. ${ }^{75}$

The various ordinances do provide for similar measures to control and regulate hunting of wild animals. ${ }^{76}$ The Cape Provincial Ordinance provides that 'endangered wild animals' may not be hunted at all at any time and in any circumstances. ${ }^{77}$ 'Protected wild animals' on the other hand may be hunted during certain times, namely hunting season, subject to permit requirements and conditions. ${ }^{78}$ Typical control measures implemented include the laying down of hunting seasons, bag limits, prohibitions on using certain types of hunting methods, ${ }^{79}$ the use of certain weapons ${ }^{80}$ and use of certain calibres of firearms in respect of certain species. ${ }^{81}$

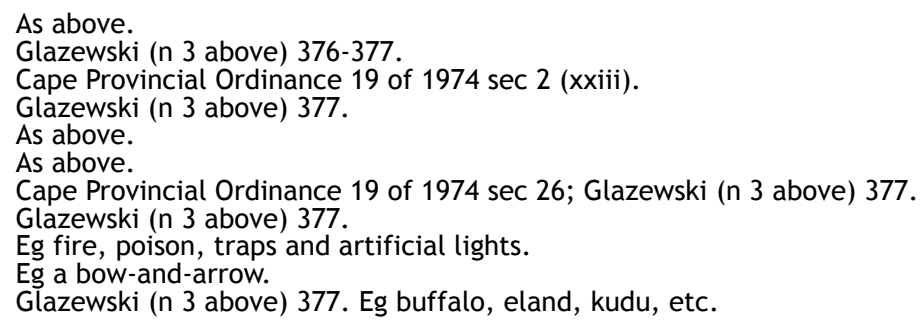




\section{The protection of wildlife in current Provincial legislation}

\subsection{Eastern Cape}

\subsubsection{The Nature Conservation Act ${ }^{82}$}

One has to consider the Ciskei Nature Conservation Act, ${ }^{83}$ hereafter referred to as 'the Act', when considering Eastern Cape legislation, as it still forms part of the legislation, in that part province that was part of the former self-governed state of Ciskei. ${ }^{84}$ Many of the provisions are similar to the Provincial Ordinances but are only written in plain and accessible English. ${ }^{85}$

The Act contains various chapters on the conservation and utilisation of wild animals, ${ }^{86}$ indigenous pants, ${ }^{87}$ nature reserves and water catchment areas, ${ }^{88}$ and fish. ${ }^{89}$ The Act also contains certain very innovative chapters which do not have counterparts in the provincial ordinance like chapters on hiking trial systems ${ }^{90}$ and sea, seashore and coastal conservation areas. ${ }^{91}$ The chapter on hiking systems includes a provision on hiking over private land. ${ }^{92}$ It is submitted that a provision like this could be a useful provision for the entire Southern South Africa.

The Act also contains a provision which resembles the 'limited development area' provision provided for in the Environmental Conservation Act, which has never been invoked, and the Transkei also has a similar Nature Conservation Act. ${ }^{93}$

\subsubsection{Legislative developments}

The Eastern Cape has instigated many public response and participation projects with the view to replace the Cape Ordinance ${ }^{94}$ and to establish its own nature conservation board. ${ }^{95} \mathrm{~A}$ draft paper,

Act 10 of 1987 (Ciskei).

Act15 (70) 25 September 1987.

Glazewski (n 3 above) 379.

As above.

Chapter 2 of the Act.

Chapter 3 of the Act.

Chapter 4 of the Act.

Chapter 7 of the Act.

Chapter 5 of the Act.

Chapter 6 of the Act.

See sec 38 of the Act.

Decree 9 (environmental conservation) Transkei in Special Gazette 70 (51) 24 July 1992.

94 Ordinance 19 of 1974

95 Glazewski (n 3 above) 380. 
the Draft Green Provincial Environmental Green Paper, ${ }^{96}$ has already been produced in order to meet this end. ${ }^{97} \mathrm{~A}$ departmental draft Nature Conservation Bill has also been produced. ${ }^{98}$ A Provincial Parks Board has also been established in terms of the Provincial Parks Board Act ${ }^{99}$ which has already been enacted. ${ }^{100}$ All of these steps will help to consolidate nature conservation laws which come from Transkei, Ciskei and the Cape Ordinance into a comprehensive Eastern Cape Nature Conservation Act. ${ }^{101}$

\subsection{Free State}

The Free State still operates under the Orange Free State Ordinance ${ }^{102}$ as discussed in paragraph 5.2.1 above. ${ }^{103} \mathrm{~A}$ Bill has however been published, namely the Free State Environmental Conservation Bill, which appears to be more focussed on environmental management than nature conservation. ${ }^{104}$ The Qwaqwa Nature Conservation $\mathrm{Act}^{105}$ is also still operative in the Free State Province. ${ }^{106}$

\subsection{Gauteng}

Gauteng Province still operates under the old Transvaal Nature Conservation Ordinance ${ }^{107}$ as discussed in paragraph 5.2.1 above. ${ }^{108}$ Like the other ordinances it includes chapters on the declaration of provincial nature reserves, ${ }^{109}$ wild animals, ${ }^{110}$ professional hunting, ${ }^{111}$ problem animals, ${ }^{112}$ fisheries, ${ }^{113}$ indigenous plants ${ }^{114}$ and endangered and rare species of fauna and flora. ${ }^{115}$ An interesting and unique chapter also provides for the trading and preservation of cave

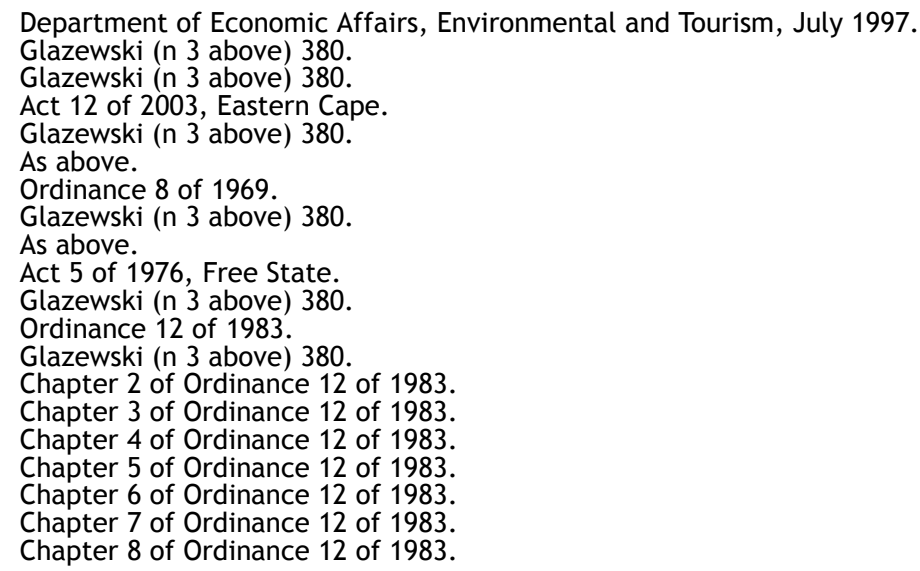


formations. ${ }^{116}$ Chapter 1 provides for the 'continued existence of the nature conservation advisory board. ${ }^{117}$

\subsection{KwaZulu-Natal}

KwaZulu-Natal Province has replaced its Nature Conservation Ordinance, ${ }^{118}$ as discussed in 5.2.1 above, with the KwaZulu-Natal Nature Conservation Management Act. ${ }^{119}$ This Act creates a new statutory body ${ }^{120}$ which replaces the former Natal Parks Board and incorporates the former KwaZulu Bureau of Natural Resources to form the KwaZulu-Natal Nature Conservation Service as well as the KwaZulu-Natal Nature Act. ${ }^{121}$ The Nature Conservation Ordinance, ${ }^{122}$ however, is still in place in conjunction with the other legislation. ${ }^{123}$

\subsection{Mpumalanga}

The Mpumalanga Province enacted the Eastern Transvaal Parks Board Act $^{124}$ after the creation of the nine new provinces but before the name changes. ${ }^{125}$ This Act established the Board and sets out its powers, functions and any other related matters. ${ }^{126}$ The title of the Act refers to the 'Parks Board' but in reality the Act applies to nature conservation in the entire province and not only in the protected areas. ${ }^{127}$ The Act states that the main object of the Board is: 'to provide effective conservation management of the natural resources of the Province, and to promote the sustainable utilisation thereof'. ${ }^{128}$ It can be seen from this that not only nature conservation but also environmental management in the entire province is the duty of this body. Included in its functions are things like "inventorying, assessing, and monitoring natural resources in the Province.'129 The Mpumalanga Nature Conservation Act ${ }^{130}$ was also passed in order to refine the old Transvaal Ordinance ${ }^{131}$ and is still in force. ${ }^{132}$ Other

116 Chapter 9 of Ordinance 12 of 1983.

117 Glazewski (n 3 above) 380.

118 Ordinance 15 of 1974

119 Act 9 of 1997, KwaZulu-Natal.

1205247 Provincial Gazette Extraordinary 18 December 1997; Glazewski (n 3 above) 380.

121 Act 29 of 1992, KwaZulu-Natal. Glazewski (n 3 above) 380.

122 Ordinance 15 of 1974.

123 Glazewski (n 3 above) 380.

124 Act 6 of 1995, Mpumalanga; N 41(89) Provincial Gazette Extraordinary 29 September 1995.

125 Glazewski (n 3 above) 380.

126 As above.

127 As above.

128 Sec 14; Glazewski (n 3 above) 381.

129 Sec 15(1)(a); Glazewski (n 3 above) 381

130 Act 10 of 1998, Mpumalanga.

13112 of 1983.

132 Glazewski (n 3 above) 381. 
Acts which are also still applicable in the province regarding nature conservation include the Bophuthatswana Nature Conservation Act, ${ }^{133}$ the Lebowa Nature Conservation Act $^{134}$ and the Kangwane Nature Conservation Act. ${ }^{135}$

\subsection{Northern Cape}

The Northern Cape Province is currently applying the Cape Nature and Environmental Conservation Ordinance. ${ }^{136}$ This is the most ill equipped province in the country concerning nature conservation as there is only one nature conservation officer for the entire province in the Department of Agriculture and Nature Conservation. ${ }^{137}$

\subsection{Limpopo}

The Limpopo Environmental Management Act $^{138}$ has recently been passed in the Limpopo Province. ${ }^{139}$ This piece of legislation has a heavy burden as it has to consolidate laws and institutions from four previous homelands which existed in its area, namely Lebowa, Venda, Gazankulu and KanGwane. ${ }^{140}$

\subsection{North West}

The North West Province has established a body corporate, the North West Parks and Tourism Board, ${ }^{141}$ in terms of the North West Parks and Tourism Board Act. The objects of the Board are not nature conservation in the broad sense but do include: ${ }^{142}$

the establishment, development, and efficient management of a network of formally protected areas in order to conserve indigenous biodiversity, representative samples of natural ecosystems and habitats of critically important or threatened species.

The board must, in addition to that, also facilitate and ensure development and promotion of tourism in the province. ${ }^{143}$ The North West Board is, therefore, only focussed on protected areas and not like some other provinces, ${ }^{144}$ where the boards are charged with

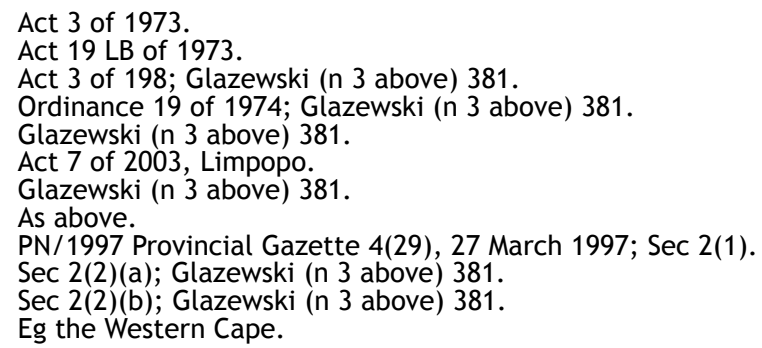


nature conservation in general. ${ }^{145}$ Other legislation still applicable in this province includes the Bophuthatswana Nature Conservation Act $^{146}$ and the Protected Areas Act (Bophuthatswana). ${ }^{147}$

\subsection{Western Cape}

The Western Cape Province has followed the trend set by KwaZuluNatal, Mpumalanga and the North West Province, and implemented the Western Cape Nature Conservation Board Act. ${ }^{148}$ The objects of the Board are 'to promote and ensure conservation and related matters in the Province.' 149 'Nature conservation' is defined in the Act as: 150

the conservation naturally occurring ecological systems and the sustainable utilisation of indigenous plants and animals and the promotion and maintenance of biological diversity, within these systems due regard to the need to preserve objects of geological, archaeological, historical, ethnological, educational, oceanographic or scientific interest.

It is clear from this that the Board in the Western Cape will not assume environmental management functions and those functions will remain the competence of the Western Cape Department of Environmental Affairs, Culture and Sport. ${ }^{151}$ This could pose a problem as this department already has its hands full with the task of performing environmental impact assessment regulations as set out in Chapter 8 . Other legislation still in force in the Province includes the Nature Conservation and Environmental Conservation Ordinance, ${ }^{152}$ the Problem Animal Control Ordinance ${ }^{153}$ and the Kango Caves Ordinance. ${ }^{154}$

Glazewski (n 3 above) 381.

Act 3 of 1975, Bophuthatswana.

Act 24 of 1987, Bophuthatswana.

Act 15 of 1998, Western Cape; Provincial Gazette Extraordinary PN 709/1998, 30

December 1998, amended by Western Cape Nature Conservation Laws Amendment Act 3 of 2000, Provincial Gazette 5442, 24 March 2000.

Sec 3(a); Glazewski (n 3 above) 381.

Sec 1(x); Glazewski (n 3 above) 382.

Glazewski (n 3 above) 382.

Ordinance 19 of 1974.

Ordinance 26 of 1957

Ordinance 5 of 1971. 


\section{Other legislation relating to wild animals}

\subsection{Animals Protection Act ${ }^{155}$}

\subsubsection{Introduction}

The object of this Act is to prevent cruelty to animals as stated in the long title. ${ }^{156}$ This Act was promulgated with domestic animals in mind but with the definition of 'animal' so wide; its application includes wild animals, birds and reptiles. ${ }^{157}$ The definition states: ${ }^{158}$

animal means any equine, bovine, sheep, goat, pig, fowl, ostrich, dog, cat or other domestic animal or bird, or any wild animal, wild bird or reptile which is in captivity or under the control of any person.

The Minister of Justice used to administer the provisions of this Act but after 1997 the Minister of Agriculture and Land Affairs has taken over its administration. ${ }^{159}$ The Society for the Prevention of Cruelty to Animals plays an important and active role in monitoring and campaigning against the cruelty of animals. ${ }^{160}$

The most important provision in this Act prohibits any type of maltreatment of animals and makes it a criminal offence subject to a fine and/or imprisonment. ${ }^{161}$ Therefore, if anybody overloads, neglects, confines any animal unnecessarily or starves or underfeeds the animal, that person would be guilty of an offence and be subject to a penalty. 162

\subsubsection{Implementation and enforcement}

The responsibility for the activities which amount to an offence as mentioned above can be imputed to the owner of the animal in question. ${ }^{163}$ The section states:

for the purposes of subsection (1), the owner of any animal shall be deemed to have permitted or procured the commission or omission of any act in relation to that animal if by the exercise of reasonable care and supervision in respect of that animal he could have prevented the commission or omission of such act. ${ }^{164}$

As above.

Sec 1; Glazewski (n 3 above) 382.

Glazewski (n 3 above) 382.

See Society for the Prevention of Cruelty to Animals, Standerton $v$ Nel and others 19884 SA 42 (W); Glazewski (n 3 above) 382.

161 Sec 2(1); Glazewski (n 3 above) 382.

162 Sec 2(a)-(s) set out the offences in detail; Glazewski (n 3 above) 382.

163 Glazewski (n 3 above) 382.

164 Sec 2(2)(2); Glazewski (n 3 above) 382. 
The court is also, in addition to the criminal sanction, empowered to grant an order for damages not exceeding the amount of R5000 where a person has, as a result of such an offence, incurred expenses like veterinary costs, food, transport, etc. ${ }^{165}$

Lastly, the Constitution has also relaxed locus standi requirements and it is now permitted for a litigant to bring an action on someone else's behalf and even if it in the public interest. ${ }^{166}$ The Societies for the Prevention of Cruelty to Animals Act ${ }^{167}$ recognises the legal standing of the SPCA in any event. ${ }^{168}$

\section{Community based wildlife conservation in South Africa ${ }^{169}$}

\subsection{General remarks}

As mentioned in above in this chapter, South Africa does not have a single coherent body of laws with regard to the environment's use and protection. ${ }^{170}$ The laws that do exist have been enacted by the national legislature, the various provincial legislatures and local authorities. ${ }^{171}$ As stated by Fuggle and Rabie ${ }^{172}$

(A) prominent feature of South African environmental legislation is its diffuse nature, with provisions being contained in an extremely wide variety of parliamentary Acts, provincial ordinances, local by-laws and ministerial regulations.

This provides for a very unsatisfactory situation because the laws protecting wildlife is extremely fragmented. ${ }^{173}$ The primary control over nature conservation is in the hands of the various provinces and the issue is dealt with through the respective provinces' ordinances. ${ }^{174} \mathrm{~A}$ result of this approach is that wildlife generally does not get protection outside of protected areas, ${ }^{175}$ and if they do it is usually limited. ${ }^{176}$ There is a clear lack of effective and integrated management and the reason for this is because the responsibility for

Sec 4(1); Glazewski (n 3 above) 382.

Sec 38 of the Constitution of the Republic of South Africa, 1996; s 4(1); Glazewski (n 3 above) 383. Act 169 of 1993.

Sec 4(1); Glazewski (n 3 above) 383.

R Summers in G Bradfield (ed) et al Environmental Justice and the Legal Process (1999) 188.

Summers (n 170 above) 203.

As above.

Fuggle \& Rabie (eds) Environmental Management in South Africa 1996; Summers (n 172 above) 203.

Summers (n 172 above) 203.

As above.

Eg national parks, nature reserves, private game reserves and state forests. Summers (n 172 above) 203-204. 
natural resource management is shared by too many different national and provincial ministries and it is, therefore, unclear where to place the blame should certain tasks not be completed. ${ }^{177}$

This means that the institutional framework, as well as the legal system, generally fail to facilitate integrated approaches to land use, including the protection of the natural environment. The Physical Planning Act 125 of 1991, the Environmental Conservation Act and the Conservation of Agricultural Resources Act assume integration of environmental management in land use planning. However, at the administrative level, environmental management practises remain sectoral and fragmented. ${ }^{178}$

There has been a growing acceptance in the South African community that when policy is formulated regarding conservation issues, the decision-makers need to take the greater socio-economic context into account. ${ }^{179}$ Part of this would be that rural communities have an important role to play in the future of wildlife conservation in South Africa. ${ }^{180}$ This is illustrated by the following paragraph: ${ }^{181}$

For any legal dispensation to be effective and enduring, it should be socially and economically relevant. South Africa is a developing country and its wildlife law must respond appropriately to its development needs and the apparent dilemma of conserving natural resources while at the same time recognising the subsistence needs of indigenous people. It is essential that the last remnants of our wildlife and its habitat be legally protected, but the laws must be so formulated and applied as to permit of controlled taking on a sustained-yield basis, particularly in those areas where the traditional way of life depends upon access to flora and fauna for food, fuel, medicine and building materials. Local people should be permitted controlled access to natural resources within such areas, or defined buffer zones, consistent with their traditional harvesting practises. Irrespective of theoretical or philosophical commitments the reality is that South African wildlife law must be human-oriented, otherwise it will not be effective. There should be provision, as a matter of law and not of administrative policy, for local participation in the protection of wildlife and natural areas, the determination of reserve boundaries and the preparation of management plans, and in the economic benefits derived from these resources.

Ridl adds to this, that South Africa should develop 'its own unique character in its law, one that accommodates the diversity of land and its people.' 182

Summers (n 172 above) 204.

White paper on South African Land Policy, April 199724.

Summers (n 172 above) 204.

As above.

Bothma \& Glavovic 'Wild Animals' in Fuggle \& Rabie (n 180 above) 258; Summers (n 173 above) 204.

JA Ridl An Environmental Law Trilogy 1992 16-17; Summers (n 173 above) 204. 


\subsection{Recent policy formulation and legislative developments}

\subsubsection{Sustainable use and conservation of biodiversity}

The Environmental Conservation $\mathrm{Act}^{183}$ is currently the most important piece of legislation regarding environmental conservation because it provides for, inter alia, the determination of policy with regard to environmental management. ${ }^{184}$ It states that policy must be developed and implemented with regard to 'the promotion of sustainable utilisation of species and ecosystems and the effective application and re-use of natural resources, 185 this clearly shows willingness on the part of the government and legislature to give effect to controlled utilisation of the environment. ${ }^{186}$ The Act also specifically provides, in the classification of protected areas, for the establishment of sustainable use areas as one of the possible six types of protected areas. ${ }^{187}$ In this regard Fuggle and Rabie state that: ${ }^{188}$

development of nature conservation and specifically the establishment and management of protected areas were to be preserved solely as sacrosanct wildlife sanctuaries. The accommodation of the lifestyles, aspirations and needs of local communities as part of the overall conservation ethic had become a globally accepted principle.

One can, therefore clearly see that South Africa is on its way to developing a sound and comprehensive policy regarding conservation, environmental management and the sustained use of natural resources. ${ }^{189}$ In addition to this, South Africa has also become a party to the Convention on Biological Diversity which came into force in December 1993 and its objects include: the conservation of biodiversity, the sustainable use of biological resources and the fair and equitable sharing of benefits arising from the use of genetic resources. ${ }^{190}$ Because South Africa is part of this Convention, it has an obligation to develop national strategies and policies in order to give effect to these objectives. ${ }^{191}$

In the national context, the Constitution must also be considered when formulating policy regarding conservation. ${ }^{192}$ It states in the Bill of Rights that every person has the right: ${ }^{193}$

84 Summers (n 172 above) 205.

185 Rabie 'Environmental Conservation' 1996 Law of South Africa 143; Summers (n 172 above) p205.

186 Summers ( 172 above) 205.

187 Sec 2(1); Summers (n 173 above) 205.

188 Fuggle \& Rabie (n 180 above) p120; Summers (n 173 above) 205.

189 Summers (n 172 above) 205.

190 White paper on the Conservation and Sustainable Use of South Africa's Biological Diversity, May 1997 p11; Summers (n 172 above) 205.

191 Summers (n 172 above) 205.

192 Summers (n 172 above) 205.

193 Sec 24, Constitution of the Republic of South Africa, 1996. 
(a) to an environment that is not harmful to their health or well-being; and

(b) to have the environment protected, for the benefit of present and future generations, through reasonable legislative and other measures that:

(i) prevent pollution and ecological degradation;

(ii) promote conservation; and

(iii) secure ecological sustainable development and use of natural resources while promoting justifiable economic and social development.

The White Paper on the Conservation and Sustainable Use of South Africa's Biological Diversity emerged out of this context. ${ }^{194}$ Chapter 2 of this paper states that one of the guiding principles is sustainable use of natural resources. ${ }^{195}$ Probably even more important than this is Policy objective 1.4 which gives recognition to the fact that natural resources outside of protected areas must also be conserved while also considering promotion of sustainable development. ${ }^{196}$ One of the potential strategies that the government is considering in order to give recognition to this policy is community-based wildlife management schemes. ${ }^{197}$ The government also explicitly stated that is will 'support the development of community-based wildlife management initiatives as part of a broader set of approaches to landuse planning and developing local sustainable development strategies. ${ }^{19}$

Added to this, government states that it will promote community participation in management of resources, both within and outside protected areas. ${ }^{199}$ The department whose role it is to formulate such policy is the Department of Environmental Affairs and Tourism (DEAT). ${ }^{200}$ Provincial government and conservation agencies are also key players in this process. ${ }^{201}$ Probably the most important roleplayers in the conservation and sustainable utilisation are the communities themselves. ${ }^{202}$ Inclusivity and participation are two of the broad principles that could be the foundation for the development of sound policy on community-based conservation. ${ }^{203}$

An important legislative development was the law commission on the Loss of Ownership of Game and the later promulgation of the

194 Summers (n 172 above) 206.

195 White paper (n 193 above) 21.

196 Summers (n 172 above) 206.

197 As above.

198 White paper (n 193 above) 34.

199 Summers (n 172 above) 206.

200 As above.

201 As above.

202 'In some instances, communities will play an important role in managing and using resources to ensure their conservation and sustainable use' White paper (n 198 above); Summers (n 172 above) 206.

203 Summers (n 172 above) 206. 
Game Theft Act ${ }^{204}$ by considering the report of the law commission. The Act can be seen as an acknowledgement of the commercial importance of wildlife regarding privately owned commercial game farms. ${ }^{205}$ Whether the legislature will ever go so far as to give ownership over natural resources to rural communities is yet to be seen, nevertheless, the basis upon which legislative development may be made in this regard is there in the waiting. ${ }^{206}$

\section{Conclusion}

If one considers the material law protection of wild animals and other living resources one could, with confidence, say that there does exist sufficient law to protect South Africa's resources. The problem is that the legislation and ordinances are extremely fragmented, so much so that it is often difficult to make sense of all the different laws applying to a specific area or jurisdiction.

A possible solution to this problem is a complete revamp of the nature conservation laws in South Africa from top to bottom, starting with enabling national legislation and proceeding to the provinces that then make legislation in accordance with their personal needs which complies with the national laws.

A final submission as a solution to the enforcement problem, as stated by Summers, ${ }^{207}$ is to involve the surrounding communities by way of education of the ecosystems and interdependent species in the area, assisting in the protection thereof and, should a profit be derived from the sustainable use and exploitation thereof, having the community share in that as well. 